\title{
PENGATURAN SUMBER DAYA PERIKANAN DI ZONA EKONOMI EKSKLUSIF (ZEE) INDONESIA
}

\author{
Ida Kurnia* \\ Bagian Hukum Internasional, Fakultas Hukum Universitas Tarumanegara, Jakarta Barat \\ Jalan Let. Jend. S. Parman Nomor 1, Jakarta Barat, D.K.I. Jakarta 11440
}

\begin{abstract}
Indonesia is an archipelago that has extensive Exclusive Economic Zone of 2,7 million $\mathrm{km}^{2}$ and has a very strategic geographical position which is between two oceans make Indonesia rich in fish resources. It is ironic that most of the fishermen living under the poverty line. With this condition, we need to reform the system of fisheries policies contained in the Indonesian EEZ.
\end{abstract}

Keywords: EEZ, fishery resources, welfare.

\section{Intisari}

Indonesia merupakan negara kepulauan yang mempunyai luas ZEE 2,7 juta $\mathrm{km}^{2}$ dan posisi geografis negara Indonesia yang sangat strategis yang diapit oleh dua samudera menjadikan Indonesia kaya akan sumber daya ikannya. Ironisnya justru tingkat kehidupan nelayannya sebagian besar berada di bawah garis kemiskinan. Kondisi ini diperlukan upaya pembenahan dalam sistem kebijakan perikanan yang terdapat di ZEE Indonesia.

Kata kunci: ZEE, sumber daya ikan, kesejahteraan.

\section{Pokok Muatan}

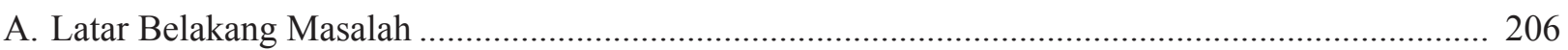

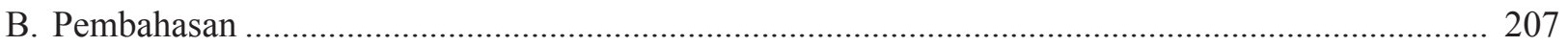

1. Perkembangan Pengaturan Sumber Daya Ikan ............................................................................... 207

2. Faktor-Faktor Pendukung Perikanan Indonesia ........................................................................ 211

3. Landasan Kebijakan Pemanfaatan Sumber Daya Ikan ............................................................... 211

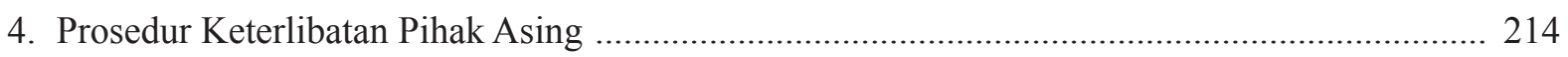

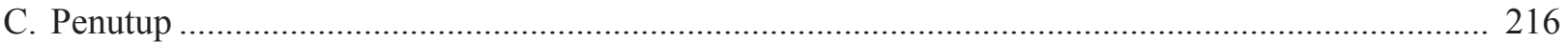

Alamat korespondensi: ida_kudus@yahoo.co.id 


\section{A. Latar Belakang Masalah}

Terbentuknya Zona Ekonomi Eksklusif $(\mathrm{ZEE})^{1}$ tidak terlepas dari sejarah perkembangan hukum laut, yaitu pengaturan dalam kewenangan penggunaan laut. Pengaturan laut yang semula hanya membagi laut menjadi dua, pertama laut yang berada di bawah kedaulatan suatu negara yang disebut dengan laut teritorial dan kedua, laut yang bersifat bebas, ${ }^{2}$ yang dalam perkembangannya pengaturan hukum laut, kemudian mengalami suatu pergeseran. Pergeseran dalam pengaturan tersebut dipicu oleh adanya pengambilan sumber daya ikan yang dilakukan secara berlebihan dan terus menerus tanpa memperhatikan faktor pelestariannya, yang pada akhirnya berdampak pengambilan sumber daya ikan yang bebas atau dapat diterjemahkan pemanfaatan tanpa batas.

Pengambilan sumber daya ikan di laut lepas tertentu yang bersambung dengan pantai sebagai sesuatu yang gratis untuk dimanfaatkan. Kondisi demikian terjadi di negara-negara yang sedang berkembang, seperti terjadi di laut lepas yang bersambung dengan pantai Meksiko. ${ }^{3}$ Tindakan dan pandangan demikian tidak dapat ditoleransi karena akan mengancam kehidupan umat manusia. Faktor penurunan sumber daya ikan, telah mendorong kesadaran untuk melihat kembali dan melakukan perbaikan tata pengaturan pemanfaatan sumber daya ikan.
Adanya kenyataan dan kondisi yang terjadi, menyebabkan klaim negara pantai untuk mengamankan dan melakukan penataan pemanfaatan laut di luar laut teritorial yang bersambung dengan laut teritorialnya. Klaim yang dilakukan oleh negara pantai ini dipelopori dan dipraktikkan oleh negara-negara Amerika, ${ }^{4}$ yang selanjutnya diikuti oleh negara-negara pantai yang lain termasuk Indonesia, dan keadaan ini mendesak untuk dibicarakan dalam hukum laut ketika mengagendakan pembicaraan hukum tentang rezim ZEE.

Berdasarkan kondisi ini pula, menyebabkan perlu dipikirkannya bagaimana laut di luar laut teritorial untuk pemanfaatannya dapat dimiliki oleh negara pantai dengan mempertimbangkan pada kepentingan negara lain. Rezim hukum internasional tentang ZEE kemudian dikembangkan oleh masyarakat internasional melalui Konferensi Perserikatan Bangsa-Bangsa tentang Hukum Laut danpraktik-praktiknegara(statepractices). Tindakan ini dimaksudkan untuk melindungi kepentingan negara pantai dari bahaya dihabiskannya sumber daya alam hayati di dekat pantainya oleh kegiatankegiatan perikanan berdasarkan rezim laut lepas. ${ }^{5}$

Perjuangan dalam mewujudkan keinginan masyarakat internasional untuk merubah pandangan, tindakan dan pengaturan terhadap pemanfaatan sumber daya ikan yang dapat merugikan kepentingan manusia dalam perjalanannya melalui proses

Penulisan Zona Ekonomi Eksklusif untuk selanjutnya ditulis ZEE. Dalam Article 55 UNCLOS, pengertian ZEE diterjemahkan suatu daerah di luar dan berdampingan dengan laut teritorial, yang tunduk pada rezim hukum khusus yang ditetapkan dalam Bab ini berdasarkan mana hakhak dan yurisdiksi negara pantai dan hak-hak serta kebebasan-kebebasan negara lain, diatur oleh ketentuan-ketentuan yang relevan Konvensi ini. Lebih lanjut, pengertian ZEE Indonesia berdasarkan Undang-Undang Nomor 5 Tahun 1983 tentang ZEE Indonesia (dalam Pasal 2) menyatakan ZEE Indonesia adalah jalur di luar dan berbatasan dengan laut wilayah Indonesia sebagaimana ditetapkan berdasarkan UndangUndang yang berlaku tentang perairan Indonesia yang meliputi dasar laut, tanah di bawahnya dan air di atasnya dengan batas terluar 200 (dua ratus) mil laut diukur dari garis pangkal wilayah Indonesia.

Penyebutan wilayah laut yang terletak di luar kedaulatan negara, dalam buku-buku hukum laut biasanya digunakan istilah laut lepas atau laut bebas. Dalam perkembangannya penyebutan laut lepas atau laut bebas dipergunakan untuk wilayah laut yang tidak termasuk wilayah laut yang berada di bawah kedaulatan suatu negara dan wilayah laut yang tidak termasuk dalam yurisdiksi maupun hak berdaulat suatu negara pantai. Kondisi pengambilan sumber daya ikan di pantai Meksiko ini terjadi sebelum dikeluarkannya Presidential Proclamation, 28 September 1945, "With Respect to Coastal Fisheries in Certain Areas of the High Seas", 10 Fed. Reg.12304.

Presiden Truman pada tahun 1945 mengambil langkah mengeluarkan Proklamasi Truman tentang Perikanan yang dinamakan dengan Presidential Proclamation, 28 September 1945, "With Respect to Coastal Fisheries in Certain Areas of the High Seas", 10 Fed. Reg.12304. Lihat Aan L. Hollick, 1981, U. S. Foreign Policy And The Law of The Sea, Princeton University Press, Princeton, New Jersey, lampiran I, tanpa hlm. Dalam rangka mengamankan sumber daya ikan di wilayah laut di luar wilayah laut teritorial dan yang berbatasan langsung dengan laut teritorial, Indonesia pada tahun 1980 mengeluarkan Pengumuman Pemerintah Republik Indonesia tentang Zona Ekonomi Eksklusif Indonesia 1980.

Kondisi ini kemudian digunakan sebagai landasan pengaturan dalam ZEE Indonesia. Lihat Penjelasan Umum, Undang-Undang Nomor 5 Tahun 1983 tentang Zona Ekonomi Eksklusif Indonesia (Lembaran Negara Republik Indonesia Tahun 1983 Nomor 44, Tambahan Lembaran Negara Republik Indonesia Nomor 3260). 
yang panjang, yaitu mulai dari konferensi PBB tentang Hukum Laut tahun 1958 yang menghasilkan Konvensi PBB tentang Hukum Laut 1958 atau United Nations Convention on the Law of the Sea I (UNCLOS I), ${ }^{6}$ konferensi PBB tentang Hukum Laut tahun 1960 atau United Nations Conference on the Law of the Sea 1960 (UNCLOS II), ${ }^{7}$ sampai pada konferensi PBB tentang Hukum Laut 1973-1982, yang menghasilkan United Nations Convention on the Law of the Sea 1982 (UNCLOS III). ${ }^{8}$ Diterimanya UNCLOS III tersebut oleh masyarakat internasional membawa konsekuensi tertentu bagi negara-negara.

Pengaturan tentang ZEE dalam UNCLOS III terdapat dalam Part $V$, yang terdiri dari 21 articles, dan 15 articles dari 21 articles mengatur mengenai perikanan yang meletakkan prinsip-prinsip bagi konservasi dan eksploitasi perikanan oleh negara pantai dan akses atas surplus perikanan bagi negara lain. Adapun pengertian ZEE menurut Article 57, sebagai berikut: "An area beyond and adjacent to the territorial sea and shall not extend beyond 200 nautical miles from the baselines from which the breadth of the territorial sea is measured". ${ }^{9}$ Artinya ketentuan batas maksimal mengenai lebar ZEE sejauh 200 mil laut ini mengisyaratkan, bahwa tidak setiap negara pantai mesti memiliki ZEE dan hanya negara pantai yang memiliki lebar wilayah laut lebih dari 24 mil laut yang memungkinkan memiliki ZEE, sepanjang tidak berbatasan langsung dengan pantai negara lain pada jarak 24 mil laut tersebut (Article 3 dan Article 57 UNCLOS 1982). ${ }^{10}$

ZEE telah merubah tatanan hukum laut dunia dan membentuk tatanan hukum laut baru dalam pemanfaatan sumber daya alam hayati (yang dapat juga berarti sumber daya perikanan) dan konservasinya. Rezim ZEE merupakan suatu pengaturan baru yang menciptakan perubahan mendasar di dalam tatanan hukum laut. Diterimanya rezim ZEE ini memberikan perluasan yurisdiksi dan memberikan posisi yang kuat sekaligus memberikan keuntungan secara ekonomis terhadap negara-negara pantai untuk memperoleh hak berdaulat guna memanfaatkan sumber daya alam hayati khususnya sumber daya perikanan yang ada di ZEE. Dikatakan memberikan keuntungan secara ekonomis karena diperkirakan 90 (sembilan puluh) persen dari jumlah tangkapan ikan secara komersial dilakukan di ZEE. ${ }^{11}$

Sejak berlakunya UNCLOS III, Indonesia sebagai negara yang turut serta memperjuangkan untuk terwujudnya pengaturan sumber daya ikan yang terdapat di ZEE, maka sebagai tindak lanjut atas komitmennya, pada tanggal 31 Desember 1985 telah meratifikasinya. Dengan demikian Indonesia telah menerima sebagai hukum positif dan menetapkannya dengan Undang-Undang Nomor 17 Tahun 1985 tentang Pengesahan United Nations Convention on the Law of the Sea $1982 .{ }^{12}$ Penetapan UNCLOS III tersebut menjadikan luas perairan Indonesia bertambah lebar.

\section{B. Pembahasan}

\section{Perkembangan Pengaturan Sumber Daya Ikan}

Sejarah pengaturan dalam hukum nasional yang berkaitan dengan kelautan dan perikanan Indonesia, sebenarnya sudah dipersiapkan dari

Menghasilkan 4 (empat) konvensi, yaitu: (1) Convention on the Territorial Sea and the Contiguous Zone, terjemahan resmi Bahasa Indonesia: Konvensi tentang Laut Teritorial dan Jalur Tambahan; (2) Convention on the High Seas, terjemahan resmi Bahasa Indonesia: Konvensi tentang Laut Lepas; (3) Convention on Fishing and Conservation of the Living Resources of the High Seas, terjemahan resmi Bahasa Indonesia: Konvensi tentang Perikanan dan Perlindungan Kekayaan Hayati Laut Lepas; (4) Convention on the Continental Shelf, terjemahan resmi Bahasa Indonesia: Konvensi tentang Landas Kontinen.

UNCLOS II merupakan kelanjutan dari konferensi PBB tentang Hukum Laut I. Pembahasannya memfokuskan pada masalah lebar laut teritorial dan sumber daya perikanan, karena dalam penetapan batas laut teritorial mempunyai dampak langsung terhadap negara-negara yang telah melakukan penangkapan ikan di perairan lepas pantai negara-negara lain. Lihat Shigeru Oda, 1989, International Control of Sea Resources, Martinus Nijhoff Publisher, Dordrecht, hlm. 99-110.

United Nations, United Nations Convention on the Law of the Sea, U.N. Doc. A/CONF.62/122, 1982.

Ibid.

Syafrinaldi, 2009, Hukum Laut Internasional, UIR Press, Pekanbaru, hlm. 19.

1 Francisco Orego Vicuna, 1984, The Exclusive Economic Zone, A Latin American Perspective, Westview Press, Colorado, hlm. 143-158.

12 Undang-Undang Nomor 17 Tahun 1985 tentang Pengesahan United Nations Convention on the Law of the Sea 1982 (Lembaran Negara Republik Indonesia Tahun 1985 Nomor 76, Tambahan Lembaran Negara Republik Indonesia Nomor 3319). 
sebelum dikeluarkannya peraturan yang mengatur secara spesifik tentang hak-hak berdaulat dalam hukum laut, khususnya yang terkait dengan sumber daya hayati (termasuk di dalamnya sumber daya ikan). Secara kronologis pengaturan sumber daya perikanan sebenarnya sudah dimulai sejak tahun 1957, yaitu sejak Indonesia mengeluarkan Pengumuman Pemerintah mengenai Wilayah Perairan Negara Republik Indonesia, yang kemudian ditingkatkan menjadi Undang-Undang Nomor 4 Prp Tahun 1960 tentang Perairan Indonesia, yang di dalam perkembangannya mengalami perubahan, yaitu dengan diundangkannya Undang-Undang Nomor 6 Tahun 1996 tentang Perairan Indonesia.

Pengumuman Pemerintah mengenai Wilayah Perairan Negara Republik Indonesia, tanggal 13 Desember 1957 oleh Perdana Menteri H. Djuanda, ${ }^{13}$ yang kemudian lazim disebut dengan Deklarasi Djuanda 13 Desember 1957, dan Undang-Undang Nomor 4 Prp Tahun 1960 tentang Perairan Indonesia, ${ }^{14}$ yang sekarang sudah dirubah dengan Undang-Undang Nomor 6 Tahun 1996 tentang Perairan Indonesia. ${ }^{15}$ Kedua aturan tersebut perlu mendapatkan perhatian, karena dalam peraturan tersebut memuat 2 (dua) hal yang pokok terkait dengan ZEE Indonesia: Pertama, yaitu adanya kedaulatan dengan wilayah darat dan laut menjadi satu kesatuan, sehingga dapat memudahkan dalam menjaga keamanan negara Indonesia, baik dalam rangka keutuhan negara Indonesia, maupun perlindungan terhadap sumber daya alam yang terkandung di dalamnya, termasuk sumber daya perikanan. Kedua, bahwa peraturan tersebut di atas merupakan awal perluasan yurisdiksi republik Indonesia dan kawasan laut yang mempunyai lebar 200 mil yang diukur dari garis pangkal yang dipergunakan untuk mengukur lebar laut teritorial.
Deklarasi Djuanda, 13 Desember 1957, mempunyai arti bahwa wilayah Indonesia bertambah luas dan yang lebih penting adalah dengan adanya pengaturan yang dituangkan dalam Deklarasi 13 Desember 1957 wilayah Indonesia menjadi satu kesatuan yang utuh dan dapat melindungi kekayaan yang terdapat di dalamnya. Dengan demikian Deklarasi Djuanda 13 Desember 1957 merupakan cikal bakal lahirnya konsepsi "nusantara" yang secara jelas dan nyata merupakan simbol kesatuan dan persatuan bangsa Indonesia yang pada saat itu telah memenuhi kebutuhan bangsa Indonesia. ${ }^{16}$ Menurut Mochtar Kusumaatmadja ada beberapa pertimbangan yang mendorong Pemerintah Republik Indonesia mengeluarkan Deklarasi Djuanda, 13 Desember 1957, sebagai berikut: ${ }^{17}$

a. Bentuk geografi negara Indonesia sebagai suatu negara kepulauan yang terdiri dari beribu-ribu pulau mempunyai sifat dan corak serta memerlukan pengaturan tersendiri.

b. Untuk kepentingan keutuhan wilayah Negara Republik Indonesia, seluruh pulau-pulau serta laut yang terletak di antaranya harus dianggap sebagai bagian dari kesatuan yang bulat.

c. Penetapan batas-batas laut teritorial yang merupakan warisan pemerintah kolonial sebagai termaktub di dalam Article 1 (1) Territoriale Zee en Maritieme Kringen Ordonnantie 1939, tidak sesuai dengan kepentingan keselamatan dan keamanan Negara Republik Indonesia.

d. Setiap negara yang berdaulat berhak untuk mengambil tindakan-tindakan dan keselamatan bagi dirinya.

\footnotetext{
13 Pengumuman Pemerintah, 13 Desember 1957, mengenai Wilayah Perairan Negara Republik Indonesia, Kabinet Perdana Menteri Republik Indonesia. Lihat Departemen Pertambangan dan Energi, 1984, Kumpulan Peraturan-Peraturan tentang Perairan Indonesia, Biro Hukum Pertambangan dan Energi, Jakarta, hlm. 34-35

14 Peraturan Pemerintah Undang-Undang Nomor 4 Tahun 1960 tentang Perairan Indonesia (Lembaran Negara Republik Indonesia Tahun 1960 Nomor 22, Tambahan Lembaran Negara Republik Indonesia Nomor 1942).

15 Undang-Undang Nomor 6 Tahun 1996 tentang Perairan Indonesia (Lembaran Negara Republik Indonesia Tahun 1996 Nomor 73 , Tambahan Lembaran Negara Republik Indonesia Nomor 3647).

6 Mochtar Kusumaatmadja, 1978, Bunga Rampai Hukum Laut, Bina Cipta, Bandung, hlm. 27-28.

17 Ibid., hlm. 26
} 
Pada awal pembentukan konsepsi nusantara sudah menjadi rencana Pemerintah Indonesia untuk dibawa ke forum internasional. Adapun maksudnya supaya tindakan-tindakan sepihak (unilateral) Indonesia untuk mewujudkan suatu konsepsi perairan nasional yang baru mendapat pengakuan untuk menjamin pelaksanaan konsepsi yang berisi keutuhan teritorial termasuk untuk melindungi kekayaan negara Indonesia diperlukan pengaturan secara internasional. Namun tindakan yang telah direncanakan oleh Indonesia pada saat diadakannya Konferensi Hukum Laut PBB yang pertama belum dapat diterima oleh negara-negara maritim besar, sehingga dalam konferensi hukum laut PBB tersebut mengenai hak-hak atas lautan yang diadakan dalam bulan Februari 1958 di Jenewa belum mendapatkan pengaturan.

Lebih lanjut dalam memperjuangkan konsepsi negara kepulauan ke forum internasional, Indonesia tidak hanya berhenti sampai disini. Dalam konferensi hukum laut PBB 1960 diajukan kembali untuk yang ke dua kalinya. Bahkan pada saat pengajuan dalam konferensi 1960, yaitu pada tanggal 18 Februari 1960 Deklarasi Djuanda sudah ditingkatkan menjadi Undang-Undang Nomor 4 Prp Tahun 1960 tentang Perairan Indonesia. Namun dalam konferensi yang ke dua ini pun konsep negara kepulauan masih belum dapat diterima.

Perjuangan bangsa Indonesia untuk mendapatkan pengakuan secara internasional terus diupayakan, mengingat Deklarasi Djuanda dicetuskan oleh Indonesia sebagai sebuah tekad politik untuk mempersatukan dan menjadikan Indonesia sebagai negara kepulauan di mana laut menjadi penghubung antar pulau dan bukan pemisah. Deklarasi Djuanda mengandung filosofi yang sangat mendasar, yaitu pengakuan wilayah untuk memperkokoh Negara Kesatuan Republik Indonesia (NKRI). ${ }^{18}$ Tanggung jawab untuk mempertahankan wilayah Indonesia sebagai negara kepulauan dan bagaimana melindungi sumber daya alam yang terkandung di dalamnya, termasuk sumber daya ikan yang merupakan aset strategis negara untuk memenuhi kepentingan ekonomi rakyat. Dengan demikian terlihat bahwa betapa pentingnya sumber daya perikanan bagi rakyat Indonesia dalam rangka untuk memenuhi kebutuhan hidup dan kepentingan yang lainnya. Oleh karena itu, pemikiran untuk mencadangkan sumber daya tersebut yang kemudian dituangkan dalam suatu pengaturan, sudah dipersiapkan oleh Indonesia sebelum adanya pengaturan dari masyarakat internasional.

Upaya untuk mencadangkan sumber daya ikan terus diperjuangkan oleh Indonesia, bahkan upaya untuk mencadangkan sumber daya ikan tidak hanya berhenti sampai di wilayah yang termasuk dalam kedaulatan negara Indonesia, namun upaya tersebut diperjuangkan terus sampai pada wilayah di luar kedaulatan negara Indonesia. Tindakan ini secara terus menerus diperjuangkan, karena perjuangan ini mempunyai konsekuensi yang logis, artinya karena wilayah perairan tersebut saling berhubungan dan bersambung, selain itu ikan merupakan sumber daya yang hidup dan selalu bergerak sehingga saling mempengaruhi, baik aspek pelestarian maupun aspek konservasinya. Pada tahun 1980, Indonesia mengeluarkan Pengumuman Pemerintah 21 Maret 1980 tentang ZEE Indonesia. Pengumuman Pemerintah 21 Maret 1980 tentang ZEE Indonesia merupakan aturan awal yang dipergunakan sebagai dasar perluasan yurisdiksi Republik Indonesia atas kawasan laut yang lebarnya 200 mil diukur dari garis-garis pangkal laut teritorial Indonesia. Menurut Koesnadi Hardjasoemantri dengan Pengumuman Pemerintah Republik Indonesia tentang ZEE Indonesia tanggal 21 Maret 1980 tersebut, Indonesia telah menambah daerah yurisdiksi sumber daya alam sebesar 2,7 juta $\mathrm{km}^{2}$ di luar 3,1 juta $\mathrm{km}^{2}$ yang tercakup di dalam perairan nusantara. ${ }^{19}$

\footnotetext{
18 Bantarto Bandoro, "Deklarasi Djuanda dalam Perspektif Politik dan Pertahanan Negara Republik Indonesia”, Makalah, Seminar Memperingati 50 Tahun Deklarasi Djuanda, Fakultas Hukum Universitas Trisakti, Jakarta, 13 Desember 2007.

19 Koesnadi Hardjasoemantri, 1988, Hukum Tata Lingkungan, Gadjah Mada University Press, Yogyakarta, hlm. 110-111.
} 
Tujuan pengumuman tersebut, seperti telah disampaikan di atas adalah untuk meningkatkan kesejahteraan rakyat Indonesia dengan memanfaatkan segenap sumber daya alam yang tersedia sehingga untuk mencapainya memerlukan pengelolaan dan perlindungan terhadap sumber daya alam yang terdapat di dasar laut dan tanah di bawahnya serta air di atasnya secara tepat, terarah dan bijaksana.

Faktor pendorong dikeluarkannya Pengumuman Pemerintah tentang ZEE Indonesia tidak terlepas dari landasan filosofi, yaitu perlunya mencadangkan sumber daya ikan untuk memenuhi kebutuhan rakyat Indonesia, dalam rangka untuk meningkatkan kesejahteraan rakyat Indonesia. Di samping itu, faktor lain yang memicu adalah adanya tindakan-tindakan atau praktik negaranegara yang menunjukkan telah diakuinya rezim ZEE selebar 200 mil laut sebagai bagian dari hukum internasional yang baru. ${ }^{20}$ Menanggapi hal tersebut, Chairul Anwar menyatakan, bahwa diakuinya ZEE di dalam hukum internasional tidak tergantung dari hasil yang dicapai UNCLOS III, oleh karena ZEE telah merupakan hukum kebiasaan internasional, sebelum konferensi hukum laut PBB ke-III berhasil menyelesaikan konferensinya. Dalam kaitan ini, bahwa di dalam pertengahan ke dua dari tahun 1970, yang pada waktu itu banyak dari negara-negara yang secara unilateral mulai memperkenalkan konsep zona 200 mil dalam praktik, penulis-penulis tentang doktrin bersangkutan mempunyai pendapat bahwa suatu proses dari perkembangan hukum yang didasarkan atas konsep ini sedang berjalan yang menuju kepada pembentukan norma hukum kebiasaan internasional. ${ }^{21}$ Sebagai akibat dari munculnya hukum kebiasaan internasional baru tentang ZEE, pada waktu Konvensi 1982 mulai berlaku, ketentuan-ketentuan ZEE dari Konvensi 1982 yang telah memperoleh status dari hukum kebiasaan internasional akan tetap mengikat semua negara-negara, apakah negara tersebut peserta atau bukan peserta dari konvensi bersangkutan. ${ }^{22}$

Dengan demikian konsep ZEE telah memperoleh dukungan yang besar dalam praktek yang dilakukan oleh negara-negara, hal ini membuktikan bahwa masyarakat internasional membutuhkan adanya pengaturan terhadap sumber daya ikan yang terdapat di ZEE-nya. Adanya komitmen bersama inilah kemudian negara-negara yang telah melakukan tindakan sepihak maupun negara yang telah sepakat untuk terikat dengan UNCLOS III, membuat peraturan nasionalnya dan kesiapan masyarakat internasional untuk menyetujui ZEE dengan lebar 200 mil laut dari garis pangkal, telah menggerakkan negara pantai untuk memaksimalkan potensi sumber daya ikan yang terdapat di dalamnya. Bagi Indonesia yang terpenting adalah bagaimana memanfaatkan potensi yang ada untuk memenuhi kebutuhan rakyatnya dan melaksanakan peraturan yang ada terkait dengan pemanfaatan surplus $^{23}$ yang tersedia, termasuk menyiapkan seperangkat pengaturan untuk mewujudkan pemanfaatan optimum sesuai dengan daya dukung yang tersedia, serta menetapkan batas-batas ZEE Indonesia dengan negara-negara tetangga di tempat-tempat perbatasan maritim ZEE yang saling tumpang tindih.

20 Salah satu faktor pendorong untuk dikeluarkannya pengumuman ZEE Indonesia tanggal 21 Maret 1980 adalah ZEE telah menjadi hukum kebiasaan internasional, dalam Pengumuman Pemerintah tentang Zona Ekonomi Eksklusif Indonesia, 21 Maret 1980. Lihat Arif Djohan Tunggal, 2010, Pokok-Pokok Hukum Laut, Harvarindo, Jakarta, hlm. 822-824. Lihat juga Barbara Kwiatkowska, 1989, The 200 Mile Exclusive Economic Zone in the New Law of the Sea, Martinus Nijhoff Publishers, Dordrecht, hlm. 27.

21 Chairul Anwar, 1994, Partisipasi Perikanan Pihak Asing di Zona Ekonomi Eksklusif Indonesia Ditinjau dari Hukum Laut Internasional, Disertasi, Program Pasca Sarjana Fakultas Hukum Universitas Indonesia, Jakarta, hlm. 341.

22 Ibid.

23 Pengertian surplus yang telah disarikan dari berbagai literatur dimaknai sebagai ketidakmampuan suatu negara pantai untuk dapat memanfaatkan seluruh Total Allowable Catch (TAC) atau Kemampuan Tangkap Nasional (KTN) tidak mencapai TAC. Pengertian TAC kemudian diterjemahkan ke dalam Bahasa Indonesia sebagai jumlah tangkapan yang diperbolehkan (JTB), sehingga surplus diartikan ketidakmampuan suatu negara pantai untuk dapat memanfaatkan seluruh JTB. Dalam peraturan nasional, menerjemahkan surplus sebagai KTN tidak mencapai JTB seperti yang diatur dalam Pasal 5 ayat (3) Undang-Undang Nomor 5 Tahun 1983 tentang Zona Ekonomi Eksklusif Indonesia (Lembaran Negara Republik Indonesia Tahun 1983 Nomor 44, Tambahan Lembaran Negara Republik Indonesia Nomor 3260). 


\section{Faktor-Faktor Pendukung Perikanan Indonesia}

Indonesia dengan adanya UNCLOS III telah menjadikan luas perairan Indonesia mencapai 5,8 juta $\mathrm{km}^{2}$ dengan perincian luas perairan kepulauan Indonesia dan laut teritorial adalah 3,1 juta $\mathrm{km}^{2}$ dan luas ZEE 2,7 juta $\mathrm{km}^{2}{ }^{24}$ dengan hak atas ZEE selebar 200 mil laut dari garis-garis pangkal yang mengelilingi seluruh nusantara Indonesia, dan telah mendapatkan pengakuan internasional. Bertambah luasnya ZEE Indonesia, menjadikan harapan sekaligus tuntutan pembangunan berbasis sumber daya perikanan agar dijadikan sebagai prime mover pembangunan nasional, pada dasarnya adalah sebuah kewajaran.

Fakta menunjukkan bahwa laut Indonesia memiliki luas 5,8 juta $\mathrm{km}^{2}$ dengan garis panjang pantai sepanjang $81.290 \mathrm{~km}^{2},{ }^{25}$ beserta sumber kekayaan alam yang terkandung di dalamnya, terutama sumber daya perikanan laut yang cukup besar, baik dari segi kuantitas maupun diversitas. ${ }^{26}$ Keadaan ini diperkuat, bahwa Indonesia dengan posisi geografis maritim yang menjadi alur pertemuan arus laut dari Samudera Pasifik ke Samudera Hindia, maupun dari arus laut dari arah utara ke selatan atau sebaliknya, maka maritim nusantara kaya dengan sumber makanan ikan, ${ }^{27}$ tentunya mempunyai daya tarik tersendiri bagi ikan-ikan. Oleh sebab itu potensi perikanannya cukup subur.

Letak geografi Indonesia juga dihadapkan pada perbatasan maritim dengan sepuluh negara, yaitu: Malaysia, Singapura, Thailand, India Filipina, Vietnam, Papua Nugini, Australia, Palau dan Timor Leste, ${ }^{28}$ dan untuk adanya kejelasan baik tentang status wilayah maupun isi yang terkandung di dalamnya, mengharuskan kepada Indonesia segera menyelesaikan masalah perbatasan dengan negaranegara tetangga. ${ }^{29}$ Kejelasan perbatasan maritim membawa dampak pada kewenangan Indonesia terhadap sumber daya yang terdapat di dalamnya termasuk pengaturan sumber daya ikan di ZEE Indonesia.

Pada sisi lain, ikan mempunyai sifat yang bergerak terus (fugitive). Ada jenis-jenis ikan yang bergeraknya secara terbatas dan menetap di ZEE Indonesia, jenis ikan ini dikategorikan sebagai jenis ikan yang tidak bermigrasi, tetapi pada jenisjenis ikan tertentu penyebarannya shared stock (tidak menetap dan bermigrasi melintasi batas negara), yaitu yang dikategorikan sebagai jenis ikan straddling fish stocks (berupaya dari ZEE suatu negara ke ZEE negara yang lain dan dari ZEE suatu negara ke laut lepas atau sebaliknya), dan highly migratory fish stocks (berupaya melintasi samudera), sehingga untuk pemanfaatannya harus senantiasa memperhatikan kepentingan negaranegara lain agar segi konservasinya tetap terjaga. Demikian ini dalam rangka untuk melaksanakan upaya konservasi berkaitan dengan stok perikanan bersama dan berupaya, karena suatu pengaturan manajemen dari stok perikanan harus dilakukan secara bersama.

\section{Landasan Kebijakan Pemanfaatan Sumber Daya Ikan}

Dalam konteks pengelolaan sumber daya ikan yang terdapat di ZEE Indonesia bagi kesejahteraan rakyat, pemerintah dalam Undang-Undang Dasar Negara Republik Indonesia 1945 telah menetapkan landasan kebijakan dan sebagai tindak

\footnotetext{
Markas Besar Angkatan Laut Jawatan Hidro-Oseanografi TNI-AL, 2006, Pulau-Pulau Kecil Terluar Negara Kesatuan Republik Indonesia, Jawatan Hidro-Oseanografi TNI-AL, Jakarta, hlm. i.

Ibid.

26 Departemen Kelautan dan Perikanan, 2005, Evaluasi Pelaksanaan Program 100 Hari Departemen Kelautan dan Perikanan, Pusat Informasi dan Pelayanan Masyarakat Departemen Kelautan dan Perikanan Republik Indonesia, Jakarta, hlm. 7.

27 Askandi Yusra, 2000, Optimalisasi Pemanfaatan Potensi Bahari untuk Kemakmuran Bangsa, Lembaga Pengkajian dan Informasi Pembangunan Bahari, Jakarta, hlm. 16.

28 Sudjatmiko dan Rusdi Ridwan, "Batas-Batas Maritim Antara Republik Indonesia dengan Negara Tetangga", Jurnal Hukum Internasional, Edisi Khusus, Desember 2004, hlm. 75-76.

29 Sengketa perbatasan negara yang kembali terjadi antara Indonesia dan Malaysia menunjukkan lemahnya kedaulatan negara. Pemerintah dan DPR hendaknya segera menyusun undang-undang tapal batas negara. Aminuddin Ilmar, "Sudah Saatnya Indonesia Memiliki Regulasi yang Menunjukkan Batas-Batas Konkrit dengan Negara Lain”, Kompas, 13 Oktober 2011.
} 
lanjut diundangkannya Undang-Undang Nomor 5 Tahun 1983 tentang ZEE Indonesia. Sebagai penjabaran lebih lanjut dari Undang-Undang yang mengatur tentang ZEE Indonesia dikeluarkan peraturan perundang-undangan khususnya untuk pengaturan di bidang sumber daya alam hayati di ZEE Indonesia dalam bentuk Peraturan Pemerintah Nomor 15 Tahun 1984. Peraturan Pemerintah Nomor 15 Tahun 1984 tentang Pengelolaan Sumber Daya Alam Hayati di ZEE Indonesia merupakan upaya dan kegiatan pemerintah untuk mengarahkan dan mengendalikan pemanfaatan sumber daya alam hayati di ZEE Indonesia.

Dasar pemanfaatan sumber daya alam hayati di ZEE Indonesia adalah mengembangkan usaha perikanan Indonesia. Oleh karena itu dalam pelaksanaannya, pemerintah mengupayakan tersedianya berbagai kemudahan untuk meningkatkan kemampuan usaha perikanan Indonesia, yaitu dengan mengadakan kerja sama antara orang atau badan hukum Indonesia yang bergerak di bidang usaha perikanan Indonesia dengan orang atau badan hukum asing dalam bentuk usaha patungan atau bentuk kerja sama lainnya menurut peraturan perundang-undangan yang berlaku. ${ }^{30}$

Persyaratan agar orang atau badan hukum asing dapat diberi kesempatan untuk melakukan penangkapan ikan di ZEE Indonesia sepanjang orang atau badan hukum Indonesia yang bergerak di bidang usaha perikanan Indonesia belum dapat sepenuhnya memanfaatkan jumlah tangkapan yang diperbolehkan berdasarkan Peraturan Pemerintah ini. ${ }^{31}$ Sedangkan yang dimaksud dengan jumlah tangkapan yang diperbolehkan adalah banyaknya sumber daya alam hayati yang boleh ditangkap dengan memperhatikan pengamanan konservasinya di ZEE Indonesia. ${ }^{32}$
Pengaturan tersebut di atas jelas menunjukkan adanya suatu keharusan bahwa orang atau badan hukum asing dapat diberi kesempatan untuk melakukan penangkapan ikan di ZEE Indonesia apabila terdapat surplus, yang dirumuskan dengan kalimat: belum sepenuhnya dapat dimanfaatkan. Dalam kaitannya dengan pengaturan pemanfaatan sumber daya perikanan, maka aspek konservasi merupakan persoalan yang penting. Maksudnya tujuan diadakannya peraturan tentang pengelolaan sumber daya alam hayati di ZEE Indonesia adalah untuk pemanfaatan yang maksimum bagi usaha perikanan Indonesia dan ketidakmampuan dalam mengoptimalkan pemanfaatan tersebut yang masih in-cover oleh jumlah tangkapan yang diperbolehkan, maka baru diperbolehkan orang atau badan hukum asing untuk memanfaatkannya.

Pasal 4, mengatur perihal konservasi, yang menentukan bahwa Menteri Kelautan dan Perikanan menetapkan JTB menurut jenis atau kelompok jenis sumber daya perikanan di sebagian atau seluruh ZEE Indonesia. ${ }^{33}$ Lebih lanjut dalam ayat berikutnya dari Pasal 4 tersebut, menyatakan penetapan JTB didasarkan pada data hasil penelitian, survei, evaluasi dan atau hasil kegiatan penangkapan ikan. ${ }^{34}$ Rangkaian kegiatan tersebut didasarkan bahwa sumber daya perikanan secara alami mempunyai daya pulih kembali (renewable) sampai batas jumlah tertentu. Artinya apabila pemanfaatan sumber daya perikanan tidak dikelola dengan baik akan memungkinkan terjadinya tekanan pemanfaatan yang melampaui Maximum Sustainable Yield (MSY) yang dapat mengakibatkan semakin menurunnya persediaan sumber daya perikanan dan tidak mustahil bahwa akan terjadi kepunahan. Hal ini berakibat mengganggu keseimbangan ekosistem baik di ZEE Indonesia maupun di perairan Indonesia

\footnotetext{
30 Pasal 2 Peraturan Pemerintah Nomor 15 Tahun 1984 tentang Pengelolaan Sumber Daya Alam Hayati di ZEE Indonesia (Lembaran Negara Republik Indonesia Tahun 1984 Nomor 23, Tambahan Lembaran Negara Republik Indonesia Nomor 3275).

31 Pasal 3 Peraturan Pemerintah Nomor 15 Tahun 1984 tentang Pengelolaan Sumber Daya Alam Hayati di ZEE Indonesia. (Lembaran Negara Republik Indonesia Tahun 1984 Nomor 23, Tambahan Lembaran Negara Republik Indonesia Nomor 3275).

32 Pasal 1 huruf e Peraturan Pemerintah Nomor 15 Tahun 1984 tentang Pengelolaan Sumber Daya Alam Hayati di ZEE Indonesia (Lembaran Negara Republik Indonesia Tahun 1984 Nomor 23, Tambahan Lembaran Negara Republik Indonesia Nomor 3275).

33 Pasal 4 ayat (1), Peraturan Pemerintah Nomor15 Tahun 1984 tentang Pengelolaan Sumber Daya Alam Hayati di ZEE Indonesia (Lembaran Negara Republik Indonesia Tahun 1984 Nomor 23, Tambahan Lembaran Negara Republik Indonesia Nomor 3275).

34 Pasal 4 ayat (2), Peraturan Pemerintah Nomor 15 Tahun 1984, tentang Pengelolaan Sumber Daya Alam Hayati di ZEE Indonesia (Lembaran Negara Republik Indonesia Tahun 1984 Nomor 23, Tambahan Lembaran Negara Republik Indonesia Nomor 3275).
} 
juga akan terganggu. Oleh karena itu, dalam rangka melestarikan sumber daya perikanan agar supaya dapat dimanfaatkan secara terus-menerus, perlu ditetapkan JTB setinggi-tingginya 90 (sembilan puluh) persen dari MSY.

Penetapan JTB dijadikan sebagai dasar oleh Menteri Kelautan dan Perikanan untuk menetapkan alokasi jumlah unit kapal perikanan dan jenis alat penangkap ikan dari masing-masing kapal. ${ }^{35}$ Penetapan demikian dimaksudkan bahwa setiap kapal perikanan yang dilengkapi dengan alat penangkap ikan tertentu mempunyai kemampuan untuk menangkap dan menghasilkan sejumlah berat dan jenis ikan tertentu sesuai dengan batas kemampuan alat tersebut yang dapat diperhitungkan secara rata-rata setiap tahunnya karena JTB menurut jenis dan kelompok jenis sumber daya perikanan hanya akan mampu menampung sejumlah kapal perikanan dengan jenis alat penangkap ikan tertentu.

Dalam landasan konstitusional, yang dirumuskan dalam Pasal 33 ayat (3) seperti telah disebutkan di atas, menentukan bahwa pemerintah merupakan pengemban amanat rakyat. Oleh karena itu berkaitan dengan sumber daya ikan, pemerintah mengejawantahkannya dalam Undang-Undang Nomor 31 Tahun 2004 tentang Perikanan ${ }^{36}$ yang telah diperbaiki menjadi Undang-Undang Nomor 45 Tahun 2009 tentang Perubahan Atas UndangUndang Nomor 31 Tahun 2004 tentang Perikanan. ${ }^{37}$

Dalam Pasal 7 ayat (4) Undang-Undang Nomor 45 Tahun 2009 tentang Perubahan Atas Undang-Undang Nomor 31 Tahun 2004 tentang Perikanan, menyatakan bahwa: Menteri menetapkan potensi dan jumlah tangkapan yang diperbolehkan sebagaimana dimaksudkan pada ayat (1) huruf b dan huruf c setelah mempertimbangkan rekomendasi dari komisi nasional yang mengkaji sumber daya ikan. ${ }^{38}$ Sedangkan yang dimaksudkan dengan huruf b dan huruf c, menyatakan sebagai berikut: pada huruf $b$, potensi dan alokasi sumber daya ikan di wilayah pengelolaan perikanan Republik Indonesia, sedangkan pada huruf c, jumlah tangkapan yang diperbolehkan di wilayah pengelolaan perikanan Republik Indonesia.

Sejalan dengan pengaturan potensi dan jumlah tangkapan yang diperbolehkan atas sumber daya ikan yang terdapat di ZEE Indonesia, Indonesia telah merefleksikan UNCLOS 1982 dalam peraturan perundang-undangan nasional. Indonesia mengaturnya dalam Keputusan Menteri Pertanian Nomor 995/Kpts/IK.210/9/99 tentang Potensi Sumber Daya Ikan dan Jumlah Tangkapan yang Diperbolehkan (JTB) di Wilayah Perikanan Republik Indonesia. Dasar pertimbangan dikeluarkannya keputusan menteri adalah dalam rangka pemanfaatan dan pengelolaan sumber daya ikan secara optimal dan bertanggung jawab (responsible fisheries), menetapkan jumlah yang boleh ditangkap dan jenis serta ukuran ikan yang tidak boleh ditangkap. Dalam rangka pembinaan dan pengembangan, pemerintah menyelenggarakan pembinaan sistem informasi dan menyelenggarakan pengumpulan, pengolahan dan penyebaran seluasluasnya mengenai data teknik dan data produksi perikanan guna menunjang pelaksanaan pengelolaan sumber daya ikan serta pengembangan usaha perikanan.

Dalam peraturan yang mengatur tentang perikanan di Wilayah Pengelolaan Perikanan Republik Indonesia (WPP-RI) ${ }^{39}$ dan sumber daya

35 Pasal 5 Peraturan Pemerintah Nomor 15 Tahun 1984 tentang Pengelolaan Sumber Daya Alam Hayati di ZEE Indonesia (Lembaran Negara Republik Indonesia Tahun 1984 Nomor 23, Tambahan Lembaran Negara Republik Indonesia Nomor 3275).

36 Secara kronologis sebelum terbentuknya Undang-Undang Nomor 31 Tahun 2004 tentang Perikanan, sudah ada Undang-Undang Nomor 9 Tahun 1985 tentang Perikanan dan Undang-Undang Nomor 31 Tahun 2004 tentang Perikanan (Lembaran Negara Republik Indonesia tahun 2004 Nomor 118, Tambahan Lembaran Negara Republik Indonesia Nomor 4433).

37 Undang-Undang Nomor 45 Tahun 2009 tentang Perubahan Atas Undang-Undang Nomor 31 Tahun 2004 tentang Perikanan (Lembaran Negara Republik Indonesia Tahun 2009 Nomor 154, Tambahan Lembaran Negara Republik Indonesia Nomor 5073).

38 Undang-Undang Nomor 45 Tahun 2009 tentang Perubahan Atas Undang-Undang Nomor 31 Tahun 2004 tentang Perikanan (Lembaran Negara Republik Indonesia Tahun 2009 Nomor 154, Tambahan Lembaran Negara Republik Indonesia Nomor 5073).

39 Berdasarkan Peraturan Menteri Kelautan dan Perikanan Republik Indonesia Nomor Per.01/Men/2009 tentang Wilayah Pengelolaan Perikanan Republik Indonesia, dalam Pasal 1 ayat (2) menyebutkan ada 11 (sebelas) Wilayah Pengelolaan Perikanan Republik Indonesia (WPP-RI). Lihat Peraturan Menteri Kelautan dan Perikanan Republik Indonesia Nomor Per.01/Men/2009 tentang Wilayah Pengelolaan Perikanan Republik Indonesia. Pusat Data Statistik dan Informasi Departemen Kelautan dan Perikanan. 
ikan di ZEE Indonesia, menyebutkan potensi dan JTB. Namun untuk kemampuan tangkapnya, dalam peraturan yang berlaku tidak menyebutkan secara tegas. Hal demikian bukan berarti tidak ada kemampuan tangkap, karena kemampuan tangkap dapat dihitung berdasarkan Surat Izin Usaha Perikanan (SIUP) yang diterbitkan, kemudian diikuti dengan jumlah kapal, ukuran kapal dan alat tangkap yang dipergunakan, serta jumlah kapal yang melapor pada pelabuhan lapor.

Walaupun untuk penentuan kemampuan tangkap dapat dilakukan perhitungan seperti di atas, kemudian berdasarkan perhitungan tersebut dapat diketahui ada atau tidak adanya surplus, namun penentuan JTB tersebut yang ditindaklanjuti dengan penetapan kemampuan tangkap sumber daya ikan di ZEE Indonesia perlu diatur secara tegas. Oleh karena rezim ZEE merupakan rezim hukum khusus, yang berarti di wilayah tersebut negara-negara lain juga memiliki hak pemanfaatan, yaitu hak akses atas surplus sumber daya ikan, yang pelaksanaannya diatur dengan suatu perjanjian (hal ini ditentukan dalam Pasal 55 UNCLOS III).

Dalam konservasi dan pemanfaatan sumber daya ikan di ZEE, UNCLOS III telah mengaturnya bahwa negara pantai diharuskan menetapkan jumlah tangkapan yang diperbolehkan sumber daya ikan di ZEE-nya dengan didasari bukti-bukti ilmiah, serta harus melakukan tindakan-tindakan untuk mencegah eksploitasi yang berlebihan. Dalam menggalakkan pemanfaatan optimal sumber daya ikan di ZEE, negara pantai diharuskan menetapkan kemampuan mengambil sumber daya ikan di ZEEnya, dan apabila kemampuan tersebut lebih dan cukup dari jumlah tangkapan yang diperbolehkan, berarti ada akses bagi pihak asing untuk dapat mengeksploitasi kelebihan jumlah tangkapan yang diperbolehkan.

\section{Prosedur Keterlibatan Pihak Asing}

Pemberian atas akses pihak asing di ZEE Indonesia memang seharusnya didasarkan pada surplus. Cara untuk mendapatkan akses atas surplus perikanan oleh pihak asing tidak diperoleh secara otomatis, tetapi ditentukan dengan perjanjian atau suatu pengaturan yang dapat dilakukan antara negara pantai dengan negara lain, secara rinci dituangkan dalam Article 62 (2, 3, 4, dan 5) UNCLOS III sebagai berikut: ${ }^{40}$

1) The coastal State shall determine its capacity to harvest the living resources of the exclusive economic zone. Where the coastal State does not have the capacity to harvest the entire allowable catch, it shall, through agreements or other arrangements and pursuant to the terms, conditions, laws and regulations referred to in paragraph 4 , give other States access to the surplus of the allowable catch, having particular regard to the provisions of articles 69 and 70 , especially in relation to the developing States mentioned therein.

2) In giving access to other States to its exclusive economic zone under this article, the coastal State shall take into account all relevant factors, including, inter alia, the significance of the living resources of the area to the economy of the coastal State concerned and its other national interest, the provisions of articles 69 and 70, the requirements of developing States in the subregion or region in harvesting part of the surplus and the need to minimize economic dislocation in State whose nationals have habitually fished in the zone or which have made substantial efforts in research and identification of stocks.

3) Nationals of the States fishing in the exclusive economic zone shall comply with the conservation measures and with the other terms and conditions established in the laws and regulations of the coastal State. These laws and regulations shall be consistent with this Convention and may relate, inter alia, to the following: licensing of fishermen, fishing vessels and equipment, including payment of fees 
and other forms of remuneration, which, in the case of developing coastal States, may consist of adequate compensation in the field of financing, equipment and technology relating to the fishing industry; determining the species which may be caught, and fixing quotas of catch, whether in relation to particular stocks or groups of stocks or catch per vessel over a period of time or to the catch by nationals of any State during a specified period; regulating seasons and areas of fishing, the types, sizes and amount of gear, and the types, sizes and number of fishing vessels that may be used; fixing the age and size of fish and other species that may be caught; specifying information required of fishing vessels including catch and effort statistics and vessel position reports; requiring, under the authorization and control of the coastal State, the conduct of specified fisheries research programmes and regulating the conduct of such research, including the sampling of catches, disposition of samples and reporting of associated scientific data; the placing of observers or trainers on board such vessels by the coastal State; the landing of all or any part of the catch by such vessels in the ports of the coastal State; term and conditions relating to joint ventures or other cooperative arrangements; requirements for the training of personnel and the transfer of fisheries technology, including enhancement of the coastal States capability of undertaking fisheries research; enforcement procedures.

4) Coastal State shall give due notice of conservation and management laws and regulations.

Dalam memberikan kesempatan kepada pihak asing untuk dapat memanfaatkan sumber daya ikan di ZEE, negara pantai harus menetapkan kemampuannya untuk memanfaatkan sumber daya ikan di ZEE, apabila negara pantai tidak dapat memanfaatkan seluruh JTB, maka JTB yang masih tersisa dapat dimanfaatkan oleh pihak asing. Faktorfaktor yang terkait dengan kepentingan negara pantai, khususnya kepentingan ekonomi rakyatnya harus mendapat perhatian, termasuk kewajiban untuk mematuhi tindakan konservasi dan kewajiban tunduk pada peraturan perundang-undangan negara pantai. Ketentuan-ketentuan dan rambu-rambu yang merupakan pedoman dalam mengatur keterlibatan pihak asing untuk memanfaatkan sumber daya ikan di ZEE tersebut, dalam pelaksanaannya oleh Indonesia belum diterapkan. Namun dalam pelaksanaannya pihak asing pada tahun 2001 sampai dengan 2006 telah berpartisipasi dalam pemanfaatan sumber daya ikan di ZEE Indonesia. ${ }^{41}$ Dalam Tata Laksana Perikanan yang Bertanggung Jawab (Code of Conduct for

41 Perjanjian antara Indonesia-Filipina, Indonesia - Thailand dan Indonesia-Cina yaitu:

(1) Arrangement between The Department of Agriculture of The Republic of The Philippines and The Ministry of Marine Affairs and Fisheries of The Republic of Indonesia on Utilization of Part of The Total Allowable Catch in The Indonesia Exclusive Economic Zone, tanggal 10 Januari 2002; (2) Memorandum of Understanding between The Ministry of Marine Affairs and Fisheries of The Republic of Indonesia and The Department of Agriculture of The Republic of The Philippines on Fisheries Cooperation, tanggal 12 November 2001; (3) Memorandum of Understanding between The Government of The Republic of Indonesia and The Government of The Republic of The Philippines on Marine and Fisheries Cooperation, tanggal 23 Februari 2006; (4) Arrangement between The Ministry of Marine Affairs and Fisheries of The Republic of Indonesia and The Ministry of Agriculture and Cooperatives of The Kingdom of Thailand on The Utilization of Part of The Total Allowable Catch in The Indonesian Exclusive Economic Zone, tanggal 16 September 2002; (5) Memorandum of Understanding between The Government of The Republic of Indonesia and The Government of The Kingdom of Thailand on Fisheries Cooperation, tanggal 17 Januari 2002; (6) Protocol Amending The Arrangement between The Ministry of Marine Affairs and Fisheries of The Republic of Indonesia and The Ministry of Agriculture and Cooperatives of The Kingdom of Thailand on The Utilization of Part of The Total Allowable Catch in The Indonesian Exclusive Economic Zone, tanggal 27 September 2003; (7) Bilateral Arrangement between The Ministry of Marine Affairs and Fisheries of The Republic of Indonesia and The Ministry of Agriculture of The People's Republic of China on The Utilization of Part of The Total Allowable Catch in Indonesian Exclusive Economic Zone, tanggal 19 Desember 2001; (8) Memorandum of Understanding between The Ministry of Agriculture of The People's Republic of China and The Ministry of Marine Affairs and Fisheries of The Republic of Indonesia on Fisheries Cooperation, tanggal 23 April 2001; (9) Memorandum of Understanding between The Ministry of Agriculture of The People's Republic of China and The Ministry of Marine Affairs and Fisheries of The Republic of Indonesia on Fisheries Cooperation, tanggal 23 April 2004; (10) Protocol Amending The Bilateral Arrangement between The Ministry of Marine Affairs and Fisheries of The Republic of Indonesia and The Ministry of Agriculture of The People's Republic of China on The Utilization of Part of The Total Allowable Catch in Indonesian Exclusive Economic Zone, tanggal 16 Juli 2004. 
Responsible Fisheries) 1995, yang kemudian disebut dengan CCRF, dalam Pasal 6 yang mengatur tentang prinsip-prinsip umum menyebutkan bahwa: Negara mempunyai kewajiban untuk menjamin adanya transparansi dalam pengambilan keputusan yang berkaitan dengan pengelolaan perikanan yang bertanggung jawab. ${ }^{42}$ Secara eksplisit ditegaskan dalam asas umum CCRF 1995 tersebut bahwa negara menetapkan aturan-aturan yang memperkuat untuk terwujudnya upaya konservasi sehingga dalam pemanfaatan sumber daya ikan di ZEE secara berkesinambungan dalam rangka untuk memenuhi kepentingan negara dapat terlaksana, dengan tanpa mengesampingkan kepentingan negara lain. Menurut Direktur Manajemen Sumber Daya Ikan, Direktorat Penangkapan Ikan, Departemen Kelautan dan Perikanan, mengatakan bahwa: ZEE Indonesia menyimpan berbagai sumber daya alam hayati yang bernilai ekonomis tinggi. Salah satunya adalah populasi berbagai jenis ikan tuna yang memberikan optimisme bagi bangsa Indonesia untuk mengembangkan industri perikanannya di masa mendatang..$^{43}$ Indonesia pada tahun 2010 sudah melakukan penangkapan ikan tuna jenis Skipjack, Albacore, Yellow Fin Tuna, Southern Bluefin Tuna dan Bigeye Tuna sebanyak 577.430 million ton dari potensi yang diestimasikan pada tahun tersebut untuk jenis-jenis ikan tuna tersebut di atas sebanyak 1.145.400 million ton. Berarti tangkapan yang belum direalisasikan sebanyak 567.970 million ton ${ }^{44}$ artinya pada satu sisi Indonesia berkewajiban berbagi dengan pihak asing dan pada sisi lain masyarakat yang bersinggungan langsung dengan sumber daya ikan tingkat kehidupan ekonominya dapat dikatakan pada garis kemiskinan.

Dalam sistem hukum, ${ }^{45}$ terutama dalam hukum nasional, pemanfaatan surplus sumber daya ikan di ZEE Indonesia belum diatur dengan jelas, dan mekanisme pemanfaatan sumber daya ikan di ZEE Indonesia yang melibatkan negara lain, berpotensi mendorong pengambil kebijakan tidak berdasarkan pada suatu bentuk kebijakan hukum yang jelas. Dalam perspektif hukum, kegiatan pemanfaatan sumber daya ikan di ZEE Indonesia mengutamakan kepentingan rakyat dan daya dukung sumber daya ikan yang tersedia, sehingga tidak terabaikannya kesejahteraan rakyat dan terkurasnya sumber daya ikan di ZEE Indonesia. Atas dasar hal tersebut diperlukan landasan pengaturan yang jelas, termasuk landasan pengaturan dalam pemberian surplus kepada pihak asing.

\section{Penutup}

Faktor-faktor yang melingkupi dan mempengaruhi keberadaan sumber daya ikan perlu mendapat pertimbangan dalam pemanfaatan sumber daya perikanan di ZEE Indonesia, artinya dalam kerangka pengaturan yang menjadi landasan dalam pemanfaatannya harus jelas, karena landasan filosofi pemanfaatan sumber daya perikanan di ZEE adalah untuk kesejahteraan rakyat negara pantai yang bersangkutan, dalam hal ini adalah kesejahteraan rakyat Indonesia. Kondisi ini memang perlu segera untuk dapat pengaturan, karena

42 Pasal 6 ayat (13) menyatakan bahwa: States should, to the extent permitted by national laws and regulations, ensure that decision making processes are transparent and achieve timely solutions to urgent matters. States, in accordance with appropriate procedures, should facilitate consultation and the effective participation of industry, fish workers, environmental and other interested organizations in decision-making with respect to the development of laws and policies related to fisheries management, development, international lending and aid. Lihat Food and Agriculture Organization of The United Nations, 1995, Code of Conduct for Responsible Fisheries, Fisheries and Aquaculture Department, Rome, hlm. 6.

43 Anonim, "Implementasi Pengamanan ZEE Indonesia dengan Modernisasi Alutsista", http://zerdream.blogspot.com/2010/05 implementasipengamanan-zee-indonesia., diakses 2 November 2010.

44 Direktur Manajemen Sumber Daya Ikan, Direktorat Perikanan Tangkap, Departemen Kelautan dan Perikanan, "Tuna Fisheries Management in Indonesia", $1^{\text {st }}$ ASEAN Tuna Working Group Meeting, Jakarta, 25-26 Mei 2011.

45 Hukum merupakan sistem berarti bahwa hukum itu merupakan tatanan, merupakan suatu kesatuan yang utuh yang terdiri dari bagian-bagian atau unsur-unsur yang saling berkaitan erat satu sama lain. Dengan perkataan lain sistem hukum adalah suatu kesatuan yang terdiri dari unsurunsur yang mempunyai interaksi satu sama lain dan bekerja sama untuk mencapai tujuan kesatuan tersebut. Lihat Sudikno Mertokusumo, 2005, Mengenal Hukum Suatu Pengantar, Liberty, Yogyakarta, hlm. 122. Menurut Lawrence M. Friedman, terminologi sistem hukum dalam arti luas mencakup tiga unsur, yaitu: struktur hukum, substansi hukum, dan budaya hukum. Lihat Lawrence M. Friedman, 1984, American Law: An Introduction, W.W. Norton \& Co., New York, hlm. 242-243. 
pada prinsipnya sumber daya ikan yang terdapat di ZEE Indonesia memiliki dimensi nasional dan internasional, menjadi sangat spesifik bila dihubungkan dengan pemanfaatan surplus sumber daya perikanan di ZEE Indonesia. Di samping itu, bidang kegiatan ini relatif menjadi perhatian banyak pihak karena kedudukannya sebagai objek vital usaha nasional tetapi ada hak akses bagi pihak asing. Peraturan Pemerintah tentang Konservasi Sumber Daya Ikan dapat dikatakan telah memberikan perhatian kepada pemerintah bahwa pengelolaan yang dilakukan selama ini telah mengindikasikan adanya inkonsistensi pengaturan, terutama pengaturan tentang pemanfaatan sumber daya ikan di ZEE Indonesia. Secara jelas dikatakan dalam Undang-Undang Nomor 5 Tahun 1983 dan Peraturan Pemerintah Nomor 15 Tahun 1984, dilakukan penggalakan pemanfaatan optimum dengan didahului penelitian adanya ketersediaan daya dukungnya, sehingga faktor pemanfaatan sumber daya ikan untuk kesejahteraan rakyat tidak terabaikan.

\section{DAFTAR PUSTAKA}

\section{A. Buku}

Departemen Kelautan dan Perikanan, 2005, Evaluasi Pelaksanaan Program 100 Hari Departemen Kelautan dan Perikanan, Pusat Informasi dan Pelayanan Masyarakat, Jakarta.

Departemen Kelautan dan Perikanan, 2006, Status Potensi Sumber Daya Ikan di 11 WPP-RI, Komisi Nasional Pengkajian Sumber Daya Ikan, Jakarta.

Departemen Pertambangan dan Energi, 1984, Kumpulan Peraturan-Peraturan tentang Perairan Indonesia, Biro Hukum Pertambangan dan Energi, Jakarta.

Friedman, Lawrence M., 1984, American Law: An Introduction, W. W. Norton \& Co., New York.

Hardjasoemantri, Koesnadi, 1988, Hukum Tata Lingkungan, Gadjah Mada University Press, Jakarta.

Hollick, Ann L., 1981, U.S. Foreign Policy and the Law of the Sea, Princeton University Press, Princeton, New Jersey.

Jawatan Hidro-Oseanografi TNI AL, 2006, PulauPulau Kecil Terluar Negara Kesatuan Republik Indonesia, Markas Besar Angkatan Laut Jawatan Hidro-Oseanografi TNI AL, Jakarta.

Kusumaatmadja, Mochtar, 1978, Bunga Rampai Hukum Laut, Bina Cipta, Bandung.
Kwiatkowska, Barbara, 1989, The 200 Mile Exclusive Economic Zone in the New Law of the Sea, Martinus Nijhoff Publishers, Dordrecht.

Markas Besar Angkatan Laut Jawatan HidroOseanografi TNI-AL, 2006, Pulau-Pulau Terkecil Terluar Negara Kesatuan Republik Indonesia, Jawatan Hidro-Oseanografi TNIAL, Jakarta.

Mertokusumo, Sudikno, 2005, Mengenal Hukum Suatu Pengantar, Liberty, Yogyakarta.

Oda, Shigeru, 1989, International Control of Sea Resources, Martinus Nijhoff Publisher, Dordrecht.

Syafrinaldi, 2009, Hukum Laut Internasional, UIR Press, Pekanbaru.

Tribawono, Djoko, 2002, Hukum Perikanan Indonesia, Citra Aditya Bakti, Bandung.

Tunggal, Arif Djohan, 2010, Pokok-Pokok Hukum Laut, Harvarindo, Jakarta.

Vicuna, Francisco Orrego, 1984, The Exclusive Economic Zone, A Latin American Perspective, Westview Press, Colorado.

Yusra, Askandi, 2000, Optimalisasi Pemanfaatan Potensi Bahari untuk Kemakmuran Bangsa, Lembaga Pengkajian dan Informasi Pembangunan Bahari, Jakarta. 


\section{B. Artikel Jurnal}

Sudjatmiko dan Ridwan Rusdi, "Batas-Batas Maritim antara Republik Indonesia dengan Negara Tetangga", Jurnal Hukum Internasional LPHI-FHUI, Edisi Khusus, 2004.

\section{Pidato}

Bandoro, Bantarto, "Deklarasi Djuanda dalam Perspektif Politik dan Pertahanan Negara Republik Indonesia", Naskah Pidato, disampaikan dalam Seminar Memperingati 50 Tahun Deklarasi Djuanda, Fakultas Hukum Universitas Trisakti Jakarta, 13 Desember 2007.

Direktur Manajemen Sumber Daya Ikan, Direktorat Perikanan Tangkap, Departemen Kelautan dan Perikanan, "Tuna Fisheries Management in Indonesia", Makalah, disampaikan dalam $1^{\text {st }}$ ASEAN Tuna Working Group Meeting, Jakarta, 2011

\section{Artikel Koran}

Ilmar, Aminuddin, "Sudah Saatnya Indonesia Memiliki Regulasi yang Menunjukkan Batas-Batas Konkrit dengan Negara Lain", Kompas, 13 Oktober 2011.

\section{E. Internet}

Anonim, "Implementasi Pengamanan ZEE Indonesia dengan Modernisasi Alutsista", http://zerdream.blogspot.com/2010/05 implementasi-pengamanan-zee-indonesia., diakses 2 November 2010.

\section{F. Peraturan Perundang-Undangan}

Undang-Undang Dasar Negara Republik Indonesia 1945 dan Amandemen Lengkap (I-IV).

Undang-Undang Nomor Prp 4 Tahun 1960 tentang Perairan Indonesia (Lembaran Negara Republik Indonesia Tahun 1960 Nomor 22, Tambahan Lembaran Negara Republik Indonesia Nomor 1942).
Undang-Undang Nomor 5 Tahun 1983 tentang Zona Ekonomi Eksklusif Indonesia (Lembaran Negara Republik Indonesia Tahun 1983 Nomor 44, Tambahan Lembaran Negara Republik Indonesia Nomor 3260).

Undang-Undang Nomor 9 Tahun 1985 tentang Perikanan (Lembaran Negara Republik Indonesia Tahun 1985 Nomor 46, Tambahan Lembaran Negara Republik Indonesia Nomor 3299).

Undang-Undang Nomor 17 Tahun 1985 tentang Pengesahan United Nations Convention on the Law of the Sea (Lembaran Negara Republik Indonesia Tahun 1985 Nomor 76, Tambahan Lembaran Negara Republik Indonesia Nomor 3319).

Undang-Undang Nomor 5 Tahun 1990 tentang Konservasi Sumber Daya Alam Hayati Dan Ekosistemnya (Lembaran Negara Republik Indonesia Tahun 1990 Nomor 49, Tambahan Lembaran Negara Republik Indonesia Nomor 3419).

Undang-Undang Nomor 6 Tahun 1996 tentang Perairan Indonesia (Lembaran Negara Republik Indonesia Tahun 1996 Nomor 73, Tambahan Lembaran Negara Republik Indonesia Nomor 3647).

Undang-Undang Nomor 31 Tahun 2004 tentang Perikanan (Lembaran Negara Republik Indonesia Tahun 2004 Nomor 118, Tambahan Lembaran Negara Republik Indonesia Nomor 4433).

Undang-Undang Nomor 43 Tahun 2008 tentang Wilayah Negara (Lembaran Negara Republik Indonesia Tahun 2008 Nomor 118, Tambahan Lembaran Negara Republik Indonesia Nomor 4433).

Undang-Undang Nomor 45 Tahun 2009 tentang Perubahan Atas Undang-Undang Nomor 31 Tahun 2004 tentang Perikanan (Lembaran Negara Republik Indonesia Tahun 2009 Nomor 154, Tambahan Lembaran Negara Republik Indonesia Nomor 5073). 
Peraturan Pemerintah Nomor 15 Tahun 1984 tentang Pengelolaan Sumber Daya Alam Hayati Di Zona Ekonomi Eksklusif Indonesia (Lembaran Negara Republik Indonesia Tahun 1984 Nomor 23, Tambahan Lembaran Negara Republik Indonesia Nomor 3275).

Peraturan Pemerintah Nomor 60 Tahun 2007 tentang Konservasi Sumber Daya Ikan (Lembaran Negara Republik Indonesia Tahun 2007 Nomor 134, Tambahan Lembaran Negara Republik Indonesia Nomor 4779).

Surat Keputusan Menteri Kelautan dan Perikanan Nomor 473a/Kpts/IK.230/ 6/1985 tentang Penetapan Jumlah Tangkapan yang Diperbolehkan di ZEE Indonesia.

Keputusan Menteri Kelautan dan Perikanan Nomor 995/Kpts/IK.210/9/99 tentang Potensi Sumber Daya Ikan dan Jumlah Tangkapan yang Diperbolehkan (JTB) di Wilayah Perikanan Republik Indonesia.

Peraturan Menteri Kelautan dan Perikanan Republik Indonesia Nomor Per.01/Men/2009 tentang
Wilayah Pengelolaan Perikanan Republik Indonesia.

Pengumuman Pemerintah Republik Indonesia tentang Zona Ekonomi Eksklusif Indonesia, 1980.

\section{G. Konvensi Internasional}

Charter of The United Nations and Statute of The International Court of Justice, 1945.

Code of Conduct for Responsible Fisheries, 1995.

United Nations Convention on the Territorial Sea and Contiguous Zone, 1958.

United Nations Convention on the High Seas, 1958.

United Nations Convention on Fishing and Conservation of the Living Resources of the High Seas, 1958.

United Nations Convention on the Continental Shelf, 1958.

United Nations Convention on the Law of the Sea, 1982.

Vienna Convention on the Law of Treaty, 1969. 